\title{
The Impact of Biodiesel Consumption by Transport on Economic Growth in the European Union
}

\author{
Mihaela Simionescu', Yuriy Bilan², Dalia Streimikiene ${ }^{3}$ \\ ${ }^{1}$ Institute for Economic Forecasting of the Romanian Academy \\ 050711, Casa Academiei, Calea 13 Septembrie nr.13, sector 5, Bucharest, Romania \\ E-mail.mihaela_mb1@yahoo.com \\ ${ }^{2}$ Tomas Bata University in Zlin \\ Mostni 5139, 76001 Zlin, Czech Republic \\ E-mail.yuriy_bilan@yahoo.co.uk \\ ${ }^{3}$ Lithuanian Institute of Agrarian Economics \\ V. Kudirkos st. 18-2, 03105 Vilnius, Lithuania \\ E-mail.Dalia.Streimikiene@lei.lt
}

cross $^{\text {ref }}$ http://dx.doi.org/10.5755/j01.ee.30.1.21831

\begin{abstract}
The actual EU strategies of sustainable development have determined a very fast increase in biodiesel consumption within the EU, especially since 2005. In line with these developments, the main aim of this paper is to evaluate the impact from biodiesel consumption by transport on economic growth of the EU. The identification of some groups of countries according to economic growth and biodiesel consumption in transport (cluster analysis) was performed. The relationship between economic growth and energy based on biodiesel consumption (panel data models and Granger causality on panel data) was assessed. In this context, using the available data, we assessed the effects of biodiesel consumption by transport on economic growth in the EU over the period 2010-2016. The results based on the panel data approach indicate a positive, but very low impact of energy obtained from biodiesel consumption by transport on the EU's economic growth. An increase in energy based on biodiesel by one thousand tons of oil equivalent generated, on average, an increase of 0.0019 percentage points in the real GDP rate in the EU during the period of 2010-2016. There is only a unidirectional Granger causality relationship between these two variables: the biodiesel consumption Granger caused the EU economic growth from 2010 to 2016. Policy recommendations should focus on the extension of biodiesel consumption for transport within the EU by establishing a higher minim percentage of biodiesel in transport.
\end{abstract}

Keywords: Biodiesel Consumption; Economic Growth; Transport; Panel Data; Granger Causality.

\section{Introduction}

Transport is necessary for any economy which strives to be efficient. The increase in energy consumption by transport has taken place due to the demand increase in developing countries, mostly BRICs (Brazil, Russia, India and China), the latter registering especially increasing GDP rates. Economic growth generates industrial production growth, and the latter always needs more movements of raw materials to/from production places as well as movements of labour force along with free movement of merchandise to the places where final consumers are.

The global demand for biofuels initially increased due to high petroleum prices, volatility of which has predetermined the need for better energy security. Some support measures have been taken by the countries with higher potential in terms of biofuels production and the effects from these measures have been positive: lower dependence on fossil fuels, higher incomes from agriculture, less environment losses as compared to fossil fuels' use.

The transport sector produces around $25 \%$ of the carbon dioxide emission, speaking globally. For reducing these emissions, the best solution is the use of biofuels. The newest technologies offered in this regard should ensure total or at least partial substitution of fossil fuels with biofuels. For road transport specifically, the biofuels are represented by biodiesel, bioethanol and biogas. Bioethanol is frequently used in combination with diesel when it comes to road transport.

Energy consumption by the transport sector represents around $30 \%$ of the total energy consumption, more than $90 \%$ of the energy in this sector fall on petroleum fossils. Various economic activities and commerce are the main reasons for merchandise transport. The fuels consumption, the noxious level and the degree of urbanization should become lower in the future. For heavy vehicles, biofuels are more necessary since their need to reducing carbon dioxide emissions is usually more acute.

The recent efforts for achieving sustainable development are also correlated with energy based on biofuels (Gozgor et $a l ., 2018)$. Renewable energy used in transport is not only designed to reduce air pollution and decelerate climate changes, contributing to environment protection, but also to achieve sustainable development based on the other two pillars: economic development and social development. A less polluted air will contribute to a better life quality, but 
biofuels consumption instead of traditional fuels to generate energy in transport should play an important role in the economic growth. However, biofuels consumption has a recent history compared to traditional sources of energy and we should check in practice if biodiesel consumption generated economic growth.

In the light of these developments, the main aim of this paper is to evaluate the impact from biodiesel consumption by transport on economic growth of the EU. Our research is in line with the long-run objective of the EU in terms of sustainable development. The Europe 2020 Strategy is specifically mentioning more efficient economy with lower greenhouse gas emissions and transport decarburization. The directive regarding energy produced from renewable resources (Directive 2009/28/EC) established some compulsory objectives in terms of renewable energy production and use. The biofuels used in transport should be sustainable and they should represent at least $10 \%$ of the fuels used by this sector. The Directive 2009/30/CE regarding fuels quality established the limits in the contents of ethanol, ethers and other oxygenic composes.

Our paper highlights the importance of biodiesel consumption by transport, a topic previously studied by Demirbas (2007) and Demirbas (2009), who limited to the economic benefits of biodiesel consumption for industry. In addition to these studies, we will focus on the benefit of biodiesel consumption in transport for the entire economy in terms of ensuring economic growth. This issue is actual and important in the context of efforts made by governments to achieve a sustainable development given the limited resources.

The panel data approach is used here to evaluate the impact from energy based on biodiesel consumption by transport on economic growth so that to establish the type of Granger causality between these two variables. The results indicated a very low, but positive effect from biodiesel use in transport on economic development. Moreover, it seems that biodiesel consumption is a determinant of economic growth, at least in case of the EU. More directives should be established by the European Commission to encourage the use of biodiesel in transport, thus leading to higher share of biodiesel consumption in every EU Member State. The infrastructure based on pipelines for biofuels should be standardized, taking into consideration the environmental, economic and assurance risks associated with various types of biofuels.

\section{Literature Review}

The fixed European targets have to play the leading role in the economic process of energy consumption. The developing economies need to consider these implications in order to adjust their national energy policies accordingly. There are not many studies analyzing the relationship between energy consumption and GDP growth. Majority of studies deal with foreign direct investments impact on GDP growth, relationship between GDP growth and employment etc. (Gedek et al., 2017). Zicka (2017) suggests that transport is playing the crucial role in energy consumption growth in developed economies. Some studies pointed out that regulatory incentives can provide the most important impact on energy efficiency improvements and utilization of renewable energy sources in transport (Jocovic et al., 2017; Redziuk et al., 2017; Vovk, 2016). Among sources of energy, biofuels are considered to be a relative new source that still needs to be more thoroughly analyzed.

We present the main results of the recent studies on the impact from energy consumption on the economy. The state of knowledge on the relationship between energy-growth is rather controversial today, because contradictory empirical results have been obtained.

Kasperowicz (2015) investigates the relationship between $\mathrm{CO} 2$ emissions and economic growth for the $18 \mathrm{EU}$ Member Countries, 1995 to 2012. The author verifies that the long-run relationship between GDP and $\mathrm{CO} 2$ emissions is negative because development of new low-carbon technologies is enabling and positive, and also because fast increase in production can be reached due to more intensive energy use under the already existing technologies. Economic growth in these countries implies more intensive use of energy which results in growing $\mathrm{CO} 2$ emissions, therefore, pollution is directly linked with economic growth and development. Kasperowicz and Streimikiene (2016) describe the relationship between energy consumption and economic growth for V4 countries and for the 14 EU "old" Member States, the study period is from 1995 to 2012.

Our empirical research is in line with Simionescu et al. (2017) who proved that energy consumption in transport based on bioethanol negatively affects economic growth, while greenhouse emissions do not have any impact on economic growth as such. The overall biofuel energy consumption in Brazil had positive impact on economic growth both in the short run and in the long run which is preferable to be also for the EU, but we will test this for the energy based on biodiesel consumption. In case of all types of energy sources and the sample of V4 countries, Kasperowicz and Streimikiene (2016) proved there was a positive relationship between energy use and economic growth in the period 1995-2012. The results reveal that energy consumption is not neutral to economic growth. Estimation of GDP equation indicates that energy consumption is positively related to economic growth and in relation to GDP growth in the V4 countries seems to be more efficient than in the Old EU countries. There is a positive relationship between energy use and economic growth.

Tolon-Becerra, Lastra-Bravo and Flores-Parra (2013) proposed a dynamic nonlinear target distribution method for increasing the share of biofuels in the fuel consumed for transportation. The proposed methodology is innovative, easy-to-use, and it attempts to contribute to the political discussion on the importance of territorial weighing of the biofuel consumption target by the actual situation in each member state. The authors applied the proposed distribution based on the following indicators: non-biofuels in the fuel consumed by transportation, non-biofuels per capita, nonbiofuels per gross domestic product (GDP), and GDP per capita, in the reference year (2005).

Al-Mulali (2015) investigates the impact of biofuel energy on economic growth, pollution, agriculture price level, and total agriculture production in 16 major biofuel energy consuming countries (data as of 2000-2010). The results show that biofuel energy increases GDP growth and reduces the level of pollution. It is recommended these 
countries should apply strategies to increase their biofuel energy without causing an increase in agriculture price level. Al-Mulal, Solarin and Ozturk (2016) investigates the influence of biofuel energy consumption on Brazil's economic growth during the period 1980-2012 by employing the Autoregressive Distributed Lag (ARDL) approach and the vector error correction model (VECM) Granger causality. The results revealed two structural breaks during the early 1980s due to the Latin American debt crisis as well as in the early 2000s due to the worries related to the increasing global spreads. The vector error correction model Granger causality revealed a feedback causal relationship between all the variables (with the exception of capital). It was found that biofuel energy consumption, capital, urbanization, and globalization increase Brazil's economic growth in the short run and in the long run.

Zaman (2017) studied the relationship between biofuel consumption, forest biodiversity, and a set of national scale indicators of per capita income, foreign direct investment (FDI) inflows, trade openness, and population density on the panel data of 12 biofuels consuming countries for the period of 2000 to 2013. Inverted U-shaped relationship between GEF biodiversity index and per capita income is detected, while there is flat/no relationship between carbon emissions and economic growth, and between forest biodiversity and economic growth models. Trade openness supports the increase of GEF biodiversity index while it decreases forest biodiversity index and biofuel consumption in a region.

Streimikiene (2013) presents the assessment of energy technologies in road transport sector based on costs and climate change impact in order to determine the most competitive transport technologies taking into account international post-Kyoto climate change mitigation policies. Capacity and quality of road infrastructure affects the overall level of transportation activity, which in turn affects how much energy is consumed by vehicles and the amount of greenhouse gases (GHG) emitted. The main indicators selected for technologies' assessment are: private costs and the life cycle of GHG emissions.

Chang and Shieh (2017) employed the data envelopment analysis (DEA) approach, with a single output (real GDP) and three inputs (labour, real capital stock, and energy consumption) to estimate the total factor energy efficiency (TFEE). There is an upward slope which is increasing as well as an upward slope and decreasing relations between the TFEE and real GDP per capita. This indicates that energy efficiency improvement does not hinder GDP growth in the EU. The authors analyzed the data on 27 EU countries: 8 in the Baltic Sea region and 19 nonBaltic Sea ones.

Tvaronaviciene et al. (2015) combined in one research such factors as energy security, economic growth, environmental health and long-term competitiveness. The authors suggest conceptual approaches towards formulating measurable aims for sustainable and internationally competitive economic developments, which at the same time would not lead to gradual degradation of environment and decline of international competitiveness in the long run. The authors present the discussion concerning the perception of energy security, future trends of energy consumption, economic growth and mode of impact of energetically secure economic growth on the environment and the level of international competitiveness.

Obradovic and Lojanica (2017) examined the causal relations between energy use, $\mathrm{CO} 2$ emissions and economic growth, using the examples of Greece and Bulgaria. The empirical findings indicate that in the long run there is causality from energy and $\mathrm{CO} 2$ emissions to economic growth in both countries. In the short run, there is no causality between energy and economic growth neither in Greece, nor in Bulgaria. Orientation on saving energy could have negative impact on economic growth.

Simionescu et al. (2017) empirically assessed the impact of energy consumption in transport based on biodiesel and bioethanol on sustainable development in terms of economic growth and greenhouse emissions. Methods: dynamic panel and panel vector-auto-regression models, Granger causality test. The energy policies should focus on higher utilization of biodiesel by the transport sector in the EU. Greenhouse emissions do not have any impact on economic growth while energy consumption in transport based on bioethanol negatively affects economic growth.

Demirbas (2007) showed that scarcity of known petroleum reserves will make renewable energy resources more attractive. The most feasible way to meet this growing demand is by utilizing alternative fuels.

The poorest group pays about 30 AUD more than the richest group. By 2010, the United States is expected to become the world's largest single biodiesel market, accounting for roughly $18 \%$ of the world biodiesel consumption, followed by Germany.

Reinhard and Zah (2009) assessed direct and indirect environmental impacts to be expected if Switzerland replaces $1 \%$ of its current diesel consumption with imports of soybean methyl ester (SME) from Brazil.

Both PME from Malaysia and SME from Brazil may cause more environmental impact than it is allowed by Swiss tax redemption on agro-biofuels (max. $60 \%$ of GHG emissions and $125 \%$ of UBP of fossil reference).

Chollacoop et al. (2013) showed that Thailand has taken various adaptation and mitigation measures, especially a strong policy push for the use carbon-neutral biofuel in its transportation sector due to a competitive advantage available in the agriculture sector of Thailand. Results indicated self-declared reduction in electricity demand, low response to renewables. Successful demonstration of bus operation on ethanol in Thailand is mentioned as giving confidence in larger projects' implementation in the future.

Escobar et al. (2014) assessed possible pathways of biodiesel use by Spanish transport sector, also overviewing the current situation. The authors obtained 5-15\% savings. The results show there are clear environmental benefits arising from the use of UCO biodiesel in Spain, especially in the context of meeting European targets in this regard and also as compared to the use of soybean biodiesel imported from Argentina.

$\mathrm{Xu}, \mathrm{Li}$ and Sun (2016) showed that prices for primary energy have been ineluctably raised up due to enormous energy consumption in China, while its economy suffers a lot from the severe energy shortage. Therefore, the authors ground the necessity of using renewable energy in China. The authors obtained $7 \%$ reduction in electricity demand. 
Development of China's biodiesel industry is highly dependent on raw materials, the sources and production capability of which are remarkably different in different regions of this huge country. Hence, developing quality standards for biodiesel production is crucial for further development of this sector.

Chang, Hwang and $\mathrm{Wu}$ (2017) suggested that lifecycle analysis of energy consumption and greenhouse gas (GHG) emission for various biofuel vehicles has been performed. The results show that the FFVs fuelled with an ethanol fuel blend of $85 \%$ switchgrass ethanol and $15 \%$ gasoline (E85) have the greatest benefits in terms of GHG emission reduction by $59.4 \%$, but suffer from $101.3 \%$ total energy consumption as compared to the baseline system.

Geng et al. (2016) made a review to reveal (1) Known and anticipated combustion characteristics and emissions products from dual fuels; (2) Toxic properties and the expected influence on engine performance; (3) And also, to identify promising alternative fuels for better emissions control over compression combustion engines. The authors obtained 0 to $10 \%$ savings. The results presented show a significant reduction of regular gas and PM emissions due to the use of alcohol/diesel dual fuel, while unregulated emissions such as methanol, ethanol, acetaldehyde, formaldehyde, ketone, have increased as compared to those from diesel fuel.

Shekarchian et al. (2017) investigated the effect of governmental policies on vehicle dependency reduction and the decrease of TTE by vehicle owners. It also proposes a novel method to calculate current and future TTEs by individuals. The authors obtained $89 \%$ savings. These outcomes can help policy makers manage more efficiently the transportation budgets, and may also help people decrease the rate of vehicle usage.

The Fixed Effect Model has the following representation:

\section{Methodology}

The methods used in this analysis correspond to the two objectives of the empirical research:

- The identification of some groups of countries according to economic growth and biodiesel consumption in transport (cluster analysis);

- The relationship between economic growth and energy based on biodiesel consumption (panel data models and Granger causality on panel data).

The proposed methods have the potential to explain the connection between economic growth and energy based on biodiesel consumption, including the Granger causality between these variables and also to make a description of the countries based on the values of these variables.

Cluster analysis is applied to identify groups of countries by economic growth and biodiesel consumption in transport. A non-hierarchical classification based on the Kmean clusters will be used. The k-average method initially uses $\mathrm{k}$ values, building groups based on them. However, this method is limited by the consideration of a prior number of clusters.

For the calculation of the distance to cluster, the Ward method is used, which involves the following steps:
- for the selected variable, we will calculate the sum of the squares of the deviations of each country in the cluster from the mean, aiming at minimizing the square of the error squares, ie minimizing the loss of information;

- at each step of the algorithm, we analyze each pair of countries that could be joined in a particular cluster and the pair that brings the least loss of information is unified. From the statistical point of view, there is no strong criterion indicating how many clusters should be formed for a certain probability. In choosing the optimal number of clusters, the following points are used:

- theoretical reasons;

- pre-use of non-hierarchical methods;

- application of variance analysis;

- graphical representation of countries.

The k-means method follows the steps below:

1. The division of $\mathrm{k}$ countries into $\mathrm{k}$ initial classes (each country is located in a separate class);

2. A country is placed in the cluster for which the centroid or average is the closest;

3. Recalculate the average for both the cluster that received the country and the cluster that lost it;

4. Repeat the last two steps above until changes are made.

The fixed-effects model is represented as:

$$
\mathrm{Y}_{\mathrm{it}}=\alpha+\mathrm{X}_{\mathrm{it}}^{1} \cdot \beta_{1}+\cdots+\mathrm{X}_{\mathrm{it}}^{\mathrm{K}} \cdot \beta_{\mathrm{K}}+\mu_{\mathrm{i}}+\mathrm{v}_{\mathrm{it}}
$$

The fixed-effect model is based on the following assumptions:

- the unobservable individual effects are represented by fixed parameters;

- the exogenous variables in matrix $\mathrm{X}$ do not correlate with idiosyncratic error $V_{i t}$, but correlate with individual fixed effects;

- the idiosyncratic errors $v_{i t}$ are independent and identically distributed $\left(\operatorname{iid}\left(0, \sigma_{v}^{2}\right)\right)$.

If there is only one explanatory variable, the model has the following representation:

$$
\mathrm{Y}_{\mathrm{it}}=\alpha+\mathrm{X}_{\mathrm{it}} \cdot \beta+\mu_{\mathrm{i}}+\mathrm{v}_{\mathrm{it}}
$$

The average in time is computed:

$$
\bar{Y}_{i .}=\alpha+\bar{X}_{i} \cdot \beta+\mu_{i}+\bar{v}_{i} \text {. }
$$

The difference between the two previous equations is determined:

$$
Y_{i t}-\bar{Y}_{i .}=\left(X_{i t}-\bar{X}_{i}\right) \cdot \beta+\left(v_{i t}-\bar{v}_{i \cdot}\right)
$$

This internal transformation is useful for calculating the fixed-effect estimator. The least squares method is used in the model (4) and the estimators for beta with fixed effects are determined.

For testing Granger causality of panel data, we start from the folowing regression:

$$
Y_{i t}=\alpha_{i}+\sum_{k=1}^{K} \beta_{i k} Y_{i(t-k)}+\sum_{k=1}^{K} \gamma_{i k} X_{i(t-k)}+\varepsilon_{i, t}
$$

The data series for $\mathrm{X}$ and $\mathrm{Y}$ are stationary. The coefficients might differ across countries (i-index for 
countries, t-index for time), but do not vary in time. The lag order is $\mathrm{K}$ and it is the same for all countries of the balanced panel. Granger causality test supposes the examination of significant effects of previous values of $\mathrm{X}$ on the current values of $\mathrm{Y}$. The null hypothesis is formulated as:

$$
\begin{gathered}
\mathrm{H} 0: \gamma_{i 1}=\gamma_{i 2}=\cdots=\gamma_{i K}=0,(\forall) i= \\
1,2, \ldots, N, \text { where } N \text { is the number of cross - } \\
\text { sections (countries) }
\end{gathered}
$$

\section{Empirical Results}

Biofuels' use share in the EU transport sector increased in 2016 as compared to 2000 by almost 5 times, while in the European Union the biofuels market grew from $0.3 \%$ in 2000 up to $5.1 \%$ in 2016. After 2005, the use of biofuels in transport suddenly grew in the EU due to the implemented strategies of sustainable development.

In the European Union, biodiesel is based on oilseeds (rapeseed and sunflower). The EU remains the largest producer of biodiesel in the entire world. Spain is the EU country with the highest production capacity of biodiesel, being followed by Germany and France.

According to Figure 1, the maximum level of biofuels in the EU was registered in 2016.

The most industrialized European countries have the highest weight of biofuels while Malta and Estonia have the lowest weights. An increase in the weight of biofuels used in transportation is expected, from $4.5 \%$ (the current value) to $27 \%$ in 2050, according to the Advanced Motor Fuels.

The biofuels market has many barriers that influence the market development. The biodiesel production cost is greater than the cost of diesel based on petroleum. Biofuels have high volatility in prices due to volatility in raw materials' prices.

Governments make investment in research in order to reduce production costs. Some of the barriers at fuels market are related to incompatibilities regarding fuels' mix in certain periods in a year (for example, the minimum temperature for using biodiesel is -15 degrees Celsius). Biodiesel needs a competitive price that could be at least more or less similar with that of diesel fuel.

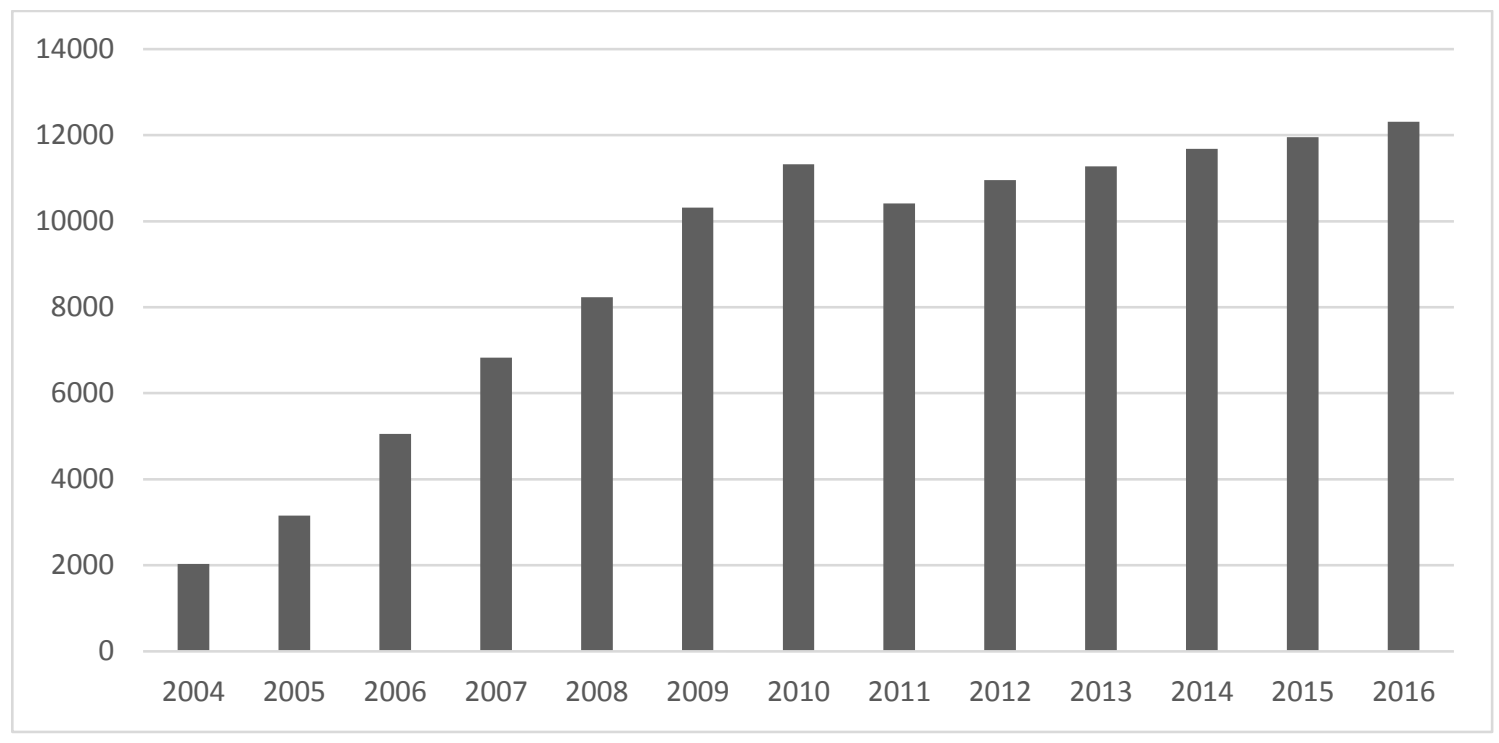

Figure 1. Biofuel Production in the EU (2005-2015) (in 1,000 Metric Tons of Oil Equivalent)

Source: authors' graph based on the Statista database

The data used in this study refers to real economic growth and is provided by the Eurostat; consumption of final energy is based on the data on biodiesel in transport (in thousand tons of oil equivalent) for which data series is provided by the World Bank. All this data is available for the 28 countries of the EU over the period 2010-2016. Data availability makes us consider short-time series only, but the panel data approach eliminates this disadvantage. The EU biodiesel market is characterized by companies' insolvences and overcapacity which are especially obvious at Germany market. Germany is the EU leading biodiesel producer. Major tax incentives were granted in Germany to support biodiesel consumption. In this rather favourable context biodiesel companies extended rapidly till 2007 (Kayhan S. et al., 2010). Then, changes in the biofuel policy diminished the price competitiveness of pure biodiesel as compared to diesel, therefore, biodiesel consumption decreased between 2007 and 2009. Our statistical data indicate that biodiesel consumption decreased in Germany in 2016 as compared to 2010 by $7 \%$, while in France it increased by $24.67 \%$ in 2016 as compared to 2010. The data for both variables in the study are stationary at $5 \%$ level of significance according to Fisher-type test based on the Augmented Dickey-Fuller test.

It is more than likely that the group of countries is heterogeneous and few clusters can be identified. The cluster analysis was conducted based on k-means method. In the first cluster we have countries with high economic growth and high biodiesel consumption like Germany and France. Cluster 2 includes the countries with rather high economic growth but less biodiesel consumption. In cluster 3 we have the countries with low economic growth, but quite large biodiesel utilization in transport, while cluster 4 includes the states with low economic growth and low biodiesel utilization in transport. Severe economic crisis in the EU, 2010 was taken into account. 
In 2016, France and Germany continued to be the leaders with high economic growth and also high biodiesel consumption by their transport sectors. It is interesting that the Baltic countries, Slovenia and Slovakia shifted in 2016 from the cluster with rather high biodiesel consumption and acceptable economic growth to the cluster with low economic growth and low utilization of biodiesel in transport. Indeed, in the Baltic countries even though their biodiesel consumption has risen, it belonged more to other sectors rather than transport. On the other hand, Greece, Bulgaria and Croatia moved in 2016 to the cluster with high biodiesel consumption in transport as compared to 2010.

A fixed effects model was estimated to explain the economic growth using the energy based on biodiesel consumption in transport over 2010-2016 in the EU-28. The OLS regression and the random effects model were found to be not valid.

$44.09 \%$ of the variation in economic growth is explained by the differences across panels. The energy based on biodiesel consumption in transport had low positive impact on economic growth, as expected. An increase in energy based on biodiesel by one thousand tonnes of oil equivalent generated, on average, an increase of 0.0019 percentage points in the real GDP rate in the EU during the period of 2010-2016. Full results are presented in Table 1, Table 2 and Table 3.

On the other hand, the Granger causality is checked for economic growth and energy based on biodiesel consumption.

Groups of Countries According to Economic Growth and Biodiesel Utilization in Transport

\begin{tabular}{|c|c|c|c|c|}
\hline Year & Cluster 1 & Cluster 2 & Cluster 3 & Cluster 4 \\
\hline 2010 & Germany, France & $\begin{array}{l}\text { Belgium, Czech Republic, } \\
\text { Denmark, Estonia, } \\
\text { Lithuania, Luxembourg, } \\
\text { Netherlands, Austria, } \\
\text { Portugal, Slovenia, } \\
\text { Slovakia, Finland, Sweden }\end{array}$ & $\begin{array}{l}\text { Spain, Italy, Poland, } \\
\text { United Kingdom }\end{array}$ & $\begin{array}{l}\text { Bulgaria, Ireland, } \\
\text { Greece, Croatia, } \\
\text { Hungary, Malta, } \\
\text { Romania }\end{array}$ \\
\hline 2016 & Germany, France & $\begin{array}{l}\text { Spain, Italy, Austria, } \\
\text { Poland, Sweden, United } \\
\text { Kingdom }\end{array}$ & $\begin{array}{l}\text { Belgium, Bulgaria, } \\
\text { Czech Republic, } \\
\text { Denmark, Greece, } \\
\text { Croatia, Cyprus, } \\
\text { Netherlands, Portugal, } \\
\text { Finland }\end{array}$ & $\begin{array}{l}\text { Estonia, Ireland, } \\
\text { Latvia, Lithuania, } \\
\text { Hungary, Malta, } \\
\text { Romania, Slovenia, } \\
\text { Slovakia }\end{array}$ \\
\hline
\end{tabular}

Source: authors' own computations

Table 2

Fixed Effects Model Explaining the EU Economic Growth Based on Energy from Biodiesel Consumption in Transport, 2010 to 2016

\begin{tabular}{|c|c|c|c|c|}
\hline Explanatory variable & Coefficient & Standard error & P>|t & 3.28 \\
\hline $\begin{array}{c}\text { Energy based on biodiesel } \\
\text { consumption }\end{array}$ & 0.0019778 & 0.0006023 & 0.001 \\
\hline Constant & 0.6342983 & 0.3313767 & 0.058 \\
\hline
\end{tabular}

Source: authors' own computations

Table 3

The Panel VAR-Granger Causality Wald Test between Real GDP Rate and Energy Based on Biodiesel Consumption in Transport in the EU, 2010 to 2016

\begin{tabular}{|c|c|c|c|}
\hline Equation & Excluded & Chi-square statistics & 5.112 \\
\hline Real GDP rate & $\begin{array}{c}\text { energy based on biodiesel } \\
\text { consumption }\end{array}$ & 0.024 \\
\hline $\begin{array}{c}\text { Energy based on biodiesel } \\
\text { consumption }\end{array}$ & real GDP rate & 0.085 & 0.771 \\
\hline
\end{tabular}

Source: authors'own computations

The results of Granger test on panel data indicate that only the energy based on biodiesel consumption in transport is a cause of economic growth, the reciprocal relationship does not seem to be valid. These results imply that higher biodiesel consumption in transport is necessary in the EU in order to increase economic growth and ensure better environmental protection. From our point of view, the role of biodiesel consumption in ensuring economic development is given by the factors like: value added to feedstock, more income taxes, more rural manufacturing jobs, more investment in equipment and plant (Demirbas, 2007). For the EU, biodiesel production seems not to be a major problem, since agricultural policy is oriented towards non-food crops' cultivation mostly. The main issue is to stimulate the consumption of biodiesel by the transport sector. The sense of causal relationship is similar with that obtained for energy consumption and economic growth in France, Turkey and West Germany over the period of 19501992 (Rauch \& Thone, 2010) and also for the cases of Italy, Slovakia, Portugal and Czech Republic (Soytas \& Sari, 2003), their study period being 1960-2002. Kayhan S. et al., (2010) confirmed this type of causality between electricity consumption and economic growth for Romania during 20012010. This type of Granger causality is typical for the EU, because for other parts of the world showed that high GDP rates 
allow for more electricity consumption (Kayhan A. et al., 2010; Karanfil \& Li, 2015; Kasperowicz et al., 2017; Pinczynski \& Kasperowicz, 2017).

The use of biofuels has impact on GDP growth, but also influences solution of strategical political issues. Biofuels influence three major policy areas: environmental policy, energy policy, and agricultural policy. These types of policies should be designed as to take into consideration the necessity of achieving economic growth.

It is possible for economic cycles and volatility of oil prices to interfere the relationship between biofuels consumption and GDP growth. Periods of economic crisis are characterized by decrease in GDP and the biofuels consumption might also be affected. However, efforts to reduce the price of biofuels should be made before as to alleviate the strong negative impact of economic crisis on the biofuels market.

\section{Conclusions}

As we stated from the very beginning, the necessity to achieve sustainable development through biofuel consumption is an important goal, but we should check on empirical data if the energy based on this type of fuels contributes to the economic growth.

Many seminal studies on the relationship between energy consumption and economy output generated conflicting, contradictory findings. This debate has brought in additional difficulties in terms of macroeconomic policies' development.

Our empirical findings show that the energy based on biodiesel consumption in transport was the cause of economic growth in the EU countries in the period of 2010-2016, but the reciprocal relationship is not valid. The energy based on biodiesel consumption in transport had a low positive impact on economic growth, as expected. An increase in energy based on biodiesel by one thousand tons of oil equivalent generated, on average, an increase by 0.0019 percentage points in real GDP rate in the EU during the period of 2010-2016. In 2016, France and Germany continued to be the leaders with high economic growth and also high biodiesel consumption in transport. It is interesting that the Baltic countries, Slovenia and Slovakia in 2016 relocated from the cluster with rather high biodiesel consumption and acceptable economic growth to the cluster with low economic growth and low use of biodiesel by transport.

The biofuel policy should promote the use in transport of fuels made from biomass, as well as other renewable fuels. Biofuels offer new economic opportunities for people in rural zones, especially from developing countries. The central policy of biofuel should focus on job creation, improvement in business environment, and environmental protection.

Biodiesel is the best alternative for diesel fuels in diesel engines. The environmental advantage is the best benefit of biodiesel compared to gasoline and petroleum diesel. Less pollution is associated to fewer expenses for environmental protection and this is also translated in better opportunities to achieve economic growth. The policy recommendations should focus in promoting biofuels consumption by reducing their price.

The study is limited by its relatively small set of data due to data availability and was addressed by using panel data models. In a future study, differences in types of biofuels should be considered in the analysis in order to make a comparative study on the impact of energy based on biofuels and economic growth.

\section{References}

Al-Mulali, U. (2015). The impact of biofuel energy consumption on GDP growth, CO2 emission, agricultural crop prices, and agricultural production. International Journal of Green Energy, 12(11), 1100-1106. https://doi.org/10.1080/ 15435075.2014.892878

Al-Mulali, U., Solarin, S. A., \& Ozturk, I. (2016). Biofuel energy consumption-economic growth relationship: an empirical investigation of Brazil. Biofuels, Bioproducts and Biorefining, 10(6), 753-775. https://doi.org/10.1002/bbb.1675

Chang, M. C., \& Shieh, H. S. (2017). The relations between energy efficiency and GDP in the Baltic sea region and nonBaltic sea region. Transformation in Business \& Economics, 16(2), 138-147.

Chang, W. R., Hwang, J. J., \& Wu, W. (2017). Environmental impact and sustainability study on biofuels for transportation applications. Renewable and Sustainable Energy Reviews, 67, 277-288. https://doi.org/10.1016/j.rser.2016.09.020

Chollacoop, N., Saisirirat, P., Sukkasi, S., Tongroon, M., Fukuda, T., Fukuda, A., \& Nivitchanyong, S. (2013). Potential of greenhouse gas emission reduction in Thai road transport by ethanol bus technology. Applied energy, 102, $112-123$. https://doi.org/10.1016/j.apenergy.2012.07.039

Demirbas, A. (2007). Importance of biodiesel as transportation fuel. Energy policy, 35(9), 4661-4670. https://doi.org/10.10 16/j.enpol.2007.04.003

Demirbas, A. (2009). Political, economic and environmental impacts of biofuels: A review. Applied energy, 86, S108S117. https://doi.org/10.1016/j.apenergy.2009.04.036

Escobar, N., Ribal, J., Clemente, G., \& Sanjuan, N. (2014). Consequential LCA of two alternative systems for biodiesel consumption in Spain, considering uncertainty. Journal of cleaner production, 79, 61-73. https://doi.org/10.10 16/j.jclepro.2014.05.065

Gedek, S., Misiak, T., \& Mentel, G. (2017). Changes in GDP and the employment and unemployment in the European Union. Transformation in Business \& Economics, 3C (42C), 440-457. 
Geng, P., Cao, E., Tan, Q., \& Wei, L. (2017). Effects of alternative fuels on the combustion characteristics and emission products from diesel engines: A review. Renewable and Sustainable Energy Reviews, 71, 523-534. https://doi.org/10.1016/j.rser.2016.12.080

Gozgor, G., Lau, C. K. M., \& Lu, Z. (2018). Energy consumption and economic growth: New evidence from the OECD countries. Energy, 153, 27-34. https://doi.org/10.1016/j.energy.2018.03.158

Jocovic, M., Milovic, N., \& Kaluderovic, J. (2017). Impact of regulatory incentives on local economic development: Montenegro case. Transformation in Business \& Economics, 2(41), 204-214.

Karanfil, F., \& Li, Y. (2015). Electricity consumption and economic growth: exploring panel-specific differences. Energy Policy, 82, 264-277. https://doi.org/10.1016/j.enpol.2014.12.001

Kasperowicz, R. (2015). Economic growth and CO2 emissions: The ECM analysis. Journal of International Studies, 8(3), 91-98.

Kasperowicz, R., \& Streimikiene, D. (2016). Economic growth and energy consumption: Comparative analysis of V4 and the «old» EU countries. Journal of International Studies, 9(2), 181-194. https://doi.org/10.14254/2071-8330.2016/9$2 / 14$

Kasperowicz, R., Pinczynski, M., Tiwari, A., \& Nawrot, L. (2017). Reengineering of electricity market monitoring. Economics \& Sociology, 10(4), 175-188. https://doi.org/10.14254/2071-789X.2017/10-4/14

Kayhan, A., Fan, X., Oommen, J., \& Oto, A. (2010). Multi-parametric MR imaging of transition zone prostate cancer: Imaging features, detection and staging. World Journal of Radiology, 2(5), 180-190. https://doi.org/10.432 9/wjr.v2.i5.180

Kayhan, S., Adiguzel, U., Bayat, T., \& Lebe, F. (2010). Causality relationship between real GDP and electricity consumption in Romania. Romanian Journal of Economic Forecasting, 4(10), 169-183.

Narayan, P. K., \& Prasad, A. (2008). Electricity consumption-real GDP causality nexus: Evidence from a bootstrapped causality test for 30 OECD countries. Energy Policy, 36(2), 910-918. https://doi.org/10.1016/j.enpol.2007.10.017

Obradovic, S., \& Lojanica, N. (2017). Energy use, CO2 emissions and economic growth-causality on a sample of SEE countries. Economic Research-Ekonomska Istrazivanja, 30(1), 511-526. https://doi.org/10.1080/13316 77X.2017.1305785

Pinczynski, M., \& Kasperowicz, R. (2016). Overview of electricity market monitoring. Economics \& Sociology, 9(4), 153167. https://doi.org/10.14254/2071-789X.2016/9-4/9

Rauch, A., \& Thone, M. (2011). Biofuels - at what cost? Mandating ethanol and biodiesel consumption in Germany. FiFo Institute for the Global Studies Initiative (GSI) de l'Institut international du développement durable (IISD), Geneve, Available from internet: http://www.globalsubsidies.org/research/biofuel-subsidies-germany.

Redziuk, A., Klymenko, O., Ageiev, V., \& Novikova, A. (2017). The concept and the development plan of national transport model of Ukraine. Journal of Sustainable Development of Transport and Logistics, 2(1), 16-28. https://doi.org/10.14254/jsdtl.2017.2-1.2

Reinhard, J., \& Zah, R. (2009). Global environmental consequences of increased biodiesel consumption in Switzerland: consequential life cycle assessment. Journal of Cleaner Production, 17, S46-S56. https://doi.org/10.1016/j.jc lepro.2009.05.003

Shekarchian, M., Moghavvemi, M., Zarifi, F., Moghavvemi, S., Motasemi, F., \& Mahlia, T. M. I. (2017). Impact of infrastructural policies to reduce travel time expenditure of car users with significant reductions in energy consumption. Renewable and Sustainable Energy Reviews, 77, 327-335. https://doi.org/10.1016/j.rser.2017.04.015

Simionescu, M., Albu, L. L., Raileanu Szeles, M., \& Bilan, Y. (2017). The impact of biofuels utilisation in transport on the sustainable development in the European Union. Technological and Economic Development of Economy, 23(4), 667686. https://doi.org/10.3846/20294913.2017.1323318

Soytas, U., \& Sari, R. (2003). Energy consumption and GDP: causality relationship in G-7 countries and emerging markets. Energy economics, 25(1), 33-37. https://doi.org/10.1016/S0140-9883(02)00009-9

Streimikiene, D. (2013). Assessment of road transport technologies based on GHG emission reduction potential and costs. Transformation in Business \& Economics, 2(29), 138-148.

Tolon-Becerra, A., Lastra-Bravo, X. B., \& Flores-Parra, I. (2013). Territorial distribution proposal for the biofuel consumption target in the transportation sector in accordance with the EU energy policy for 2020. Journal of Energy Engineering, 139(4), 253-265. https://doi.org/10.1061/(ASCE)EY.1943-7897.0000131

Tvaronaviciene, M., Maciulis, A., Lankauskiene, T., Raudeliuniene, J., \& Dzemyda, I. (2015). Energy security and sustainable competitiveness of industry development. Economic Research-Ekonomska Istrazivanja, 28(1), 502-515. https://doi.org/10.1080/1331677X.2015.1082435 
Mihaela Simionescu, Yuriy Bilan, Dalia Streimikiene. The Impact of Biodiesel Consumption by Transport on Economic...

Vovk, Y. (2016). Resource-efficient intelligent transportation systems as a basis for sustainable development. Overview of initiatives and strategies. Journal of Sustainable Development of Transport and Logistics, 1(1), 6-10. https://doi.org/10.14254/jsdtl.2016.1-1.1

Xu, Y. J., Li, G. X., \& Sun, Z. Y. (2016). Development of biodiesel industry in China: Upon the terms of production and consumption. Renewable and Sustainable Energy Reviews, 54, 318-330. https://doi.org/10.1016/j.rser.2015.10.035

Zaman, K. (2017). Biofuel consumption, biodiversity, and the environmental Kuznets curve: Trivariate analysis in a panel of biofuel consuming countries. Environmental Science and Pollution Research, 24(31), 24602-24610. https://doi.org/10.1007/s11356-017-0087-y

Zicka, M. (2017). An assessment of the efficiency and effectiveness of the services of urban transport operators in the Czech Republic. Transformation in Business \& Economics, 1(40), 134-153.

The article has been reviewed.

Received in October 2018; accepted in February 2019. 